\title{
Prevalence OF ZINC DEFICIENCY AMONG PRIMARY SCHOOL CHILDREN IN A POOR PERI-URBAN INFORMAL SETTLEMENT IN SOUTH Africa
}

Authors :

Folake O. Samuel ${ }^{1,2}$

Abdulkadir A. Egal ${ }^{1}$

Wilna H. Oldewage-

Theron $^{1}$

Carin E. Napier ${ }^{3}$

Christine S. Venter ${ }^{1,4}$

\section{Affiliations:}

${ }^{1}$ Institute of Sustainable

Livelihoods, Vaal

University of Technology,

South Africa

${ }^{2}$ Department of Human

Nutrition, Faculty of

Public Health, University

of Ibadan, Nigeria

${ }^{3}$ Department of Food and Nutrition Consumer Sciences, Durban

University of Technology,

Steve Biko campus,

South Africa

${ }^{4}$ School of Physiology,

Nutrition and Consumer

Sciences, North-West

University, Potchefstroom campus, South Africa

\section{Correspondence to}

Wilna Oldewage-Theron

email:

wilna@vut.ac.za

\section{Postal address:}

Institute of Sustainable

Livelihoods, Vaal

University of Technology,

Private Bag X021,

Vanderbijlpark 1900,

South Africa

Keywords:

deficiency; diet; poverty; vulnerable; zinc;

prevalence

Dates:

Received: 03 Apr. 2009

Accepted: 04 Nov. 2009

Published: 11 May 2010

How to cite this article:

Samuel, F.O., Egal, A.A.,

Oldewage-Theron, W.H.,

Napier, C.E. \& Venter,

C.S., 2010, 'Prevalence of

zinc deficiency among

primary school children in

a poor peri-urban informal

settlement in South Africa',

Health SA Gesondheid 15(1),

Art \#433, 6 pages. DOI:

10.4102/hsag.v15i1.433

This article is available at:

http:/ /www.hsag.co.za

\section{ABSTRACT}

This cross-sectional study assessed the risk of zinc deficiency in randomly selected children, aged between 7 and 11 years, living in a poor, peri-urban informal settlement in South Africa. Dietary intake of 149 respondents was evaluated by 24-hour recall and quantitative food frequency questionnaires. Anthropometric and biochemical indices of a subset of 113 were determined. Descriptive statistics, analysis of variance and Pearson correlations were computed using the Statistical Package for Social Sciences, version 14.0. Anthropometric data were analysed using the World Health Organization Anthro plus version 1.0.2 statistical software. Dietary data were analysed with FoodFinder ${ }^{\circledR}$ version 3. The mean age of the children was $9.0 \pm 1.1$ years. Few zinc-rich sources appeared in the diet that was predominantly plant-based. Mean dietary zinc intake was $4.6 \pm 2.2 \mathrm{mg} /$ day. The mean value of serum zinc was $66.4 \pm 21.5 \mu \mathrm{g} / \mathrm{dL}$, with $46 \%$ of the children having values less than the $70 \mu \mathrm{g} / \mathrm{dL}$ cutoff. The findings indicate a high risk of zinc deficiency and suboptimal zinc status for the majority of this study population of children, possibly as a result of low consumption of food sources with high bioavailability of zinc, which invariably is a direct consequence of poverty and food insecurity.

\section{OPSOMMING}

Die doel van hierdie dwarsdeursnitstudie was die bepaling van die risiko van 'n sinktekort in ' $n$ ewekansige steekproef van 7 tot 11 jaar-oue kinders, woonagtig in ' $n$ arm, voorstedelike informele woonbuurt in Suid Afrika. Dieetinnames van 149 respondente is geëvalueer deur 24uur herroep en kwantitatiewe voedselfrekwensie vraelyste. Antropometriese en biochemiese indikatore van 'n kleiner steekproef van 113 is ook bepaal. Beskrywende statistiek, analise van variansie en Pearsonkorrelasies is bepaal deur die Statistical Package for Social Sciences, uitgawe 14.0. Antropometriese data is geanaliseer deur die statistiese program, Anthro plus, uitgawe 1.0.2, van die Wêreld Gesondheid Organisasie. Dieetdata is met behulp van FoodFinder ${ }^{\circledR}$ uitgawe 3 geanaliseer. Die gemiddelde ouderdom van die kinders was $9.0 \pm 1.1$ jaar. Min sinkryke voedselbronne is in die hoofsaaklik plantryke dieet waargeneem. Die gemiddelde sinkinname was $4.6 \pm 2.2 \mathrm{mg} / \mathrm{dag}$ en die gemiddelde serumsinkwaarde was $66.4 \pm 21.5 \mu \mathrm{g} / \mathrm{dL}$, met $46 \%$ van die kinders se waardes onder die $70 \mu \mathrm{g} / \mathrm{dL}$ afsnypunt. Die bevindings dui op'n hoë risiko vir sinktekort en suboptimale sinkstatus vir die meerderheid van hierdie kinders, moontlik as gevolg van die swak inname van voedselbronne met hoë biobeskikbare sink, wat gewoonlik 'n direkte gevolg van armoede en huishoudelike voedsel insekuriteit is.

\section{INTRODUCTION}

In recent decades, there has been heightened interest in the role of zinc in human nutrition research. Zinc plays an indispensable role as a key component of a host of enzymes that are crucial for optimal metabolism and body function (International Zinc Nutrition Consultative Group [IZiNCG] 2007:1). In addition, zinc is an anti-inflammatory and antioxidant agent and also functions in cell-mediated immune processes (Prasad 2007:1345). Zinc deficiency has far-reaching effects, particularly in children, contributing to stunted growth (Brown, Wuehler \& Peerson 2001:114), as well as morbidity from diarrhoea, pneumonia and malaria (Shankar 2000:S38). In childhood, dietary zinc ensures optimal physical growth (Gibson 2006:54) as well as neuro-behavioural and brain development (Gibson 2006:55). Zinc deficiency may undermine cognitive development in children through alteration in attention, activity and other aspects of neuropsychological function (Black 1998:464S). As it compromises the development of millions of children in developing and industrialised countries, zinc deficiency is a veritable public health concern (Gibson 2006:53).

Global estimates of zinc deficiency in paediatric or other populations are lacking. However, based on an estimated prevalence of inadequate intakes obtained from various national food supplies (including absorbable zinc content), the global prevalence of zinc deficiency is estimated to be $31 \%$ (range is $4 \%-$ $73 \%$ ) with a high prevalence (i.e. $37 \%-62 \%$ ) found in southern and central African regions (Caulfield \& Black 2004:261). Pockets of inadequate zinc intakes have also been identified among segments of the South African population, such as infants (Oelofse et al. 2002:290), children (Faber, Jogessar \& Benadé 2001:401) and the elderly (Charlton et al. 2001:31). The 1999 National Food Consumption Survey (NFCS) was the first ever survey in South Africa that provided estimates on food consumption and the contribution various foods make to the nutrient intake of children between the ages of 1 and 9 years using a nationally representative sample (Labadarios et al. 2005:489). Nationally, 45.3\% of children of this age group (1-9 years) had an inadequate zinc intake and were considered by the authors to be at risk for zinc deficiency.

Dietary inadequacy is a key factor in the aetiology of zinc deficiency. Other aspects include disease states that induce excessive losses or impaired utilisation of zinc and physiological states that increase 
zinc requirements (Gibson 2006:54). Achieving dietary adequacy of zinc may be difficult in developing countries, particularly in resource-poor communities, as zinc-rich foods, such as meat and fish, are usually priced beyond the reach of many households. Invariably, there is heavy reliance on cheaper, plant-based diets which are not only poor in zinc content, but may also be hindering the bioavailability of zinc (Gibson 1994:152). Such diets or dietary compositions consist largely of cereals and legumes which contain high levels of phytate, a potent antagonist of zinc absorption (Gibson 2005:714, 717; Mazariegos et al. 2006:62) which has been associated with poor zinc status in a study of children in Malawi (Manary et al. 2002:1057).

Given the nationwide prevalence of inadequate intake of zinc and its adverse consequences on the health and development of children, the aim of this study was to assess the prevalence of zinc deficiency (based on dietary intake and serum zinc) among primary school children living in a poor, peri-urban informal settlement in South Africa. Engelbrecht and Du Rand (2001:830) defined informal settlements as areas where homes that do not necessarily conform to building regulations are erected. Squatting is commonplace and homes are erected using mainly cheap materials such as corrugated iron, cardboard, plastic and mud. Basic municipal services, such as water piped into homes, electricity and garbage removal, may be absent. High levels of poverty with chronic food insecurity have been observed in various informal settlements in South Africa (Dannhauser et al. 2000:303; Hugo-Hamman et al. 1987:353; Oldewage-Theron et al. 2004:315). However, there is a dearth of research on the zinc status of school-aged children living under such circumstances.

\section{RESEARCH METHOD AND DESIGN Research approach}

The Vaal region of South Africa is an industrial area that is situated approximately 70 kilometres south of Johannesburg in the Gauteng province. It has a population of 794599 , of which $47.9 \%$ are unemployed, with $46.1 \%$ of households in the area living in poverty (McIlrath \& Slabbert 2003:13). This communitybased descriptive research was done in one of the peri-urban informal settlements, consisting of 1261 Black households. A confidentiality clause was included in the agreement signed between the community and the researchers, indicating that the name of the settlement would not be mentioned in any publications and for this reason the community will be referred to as 'an informal settlement in the Vaal region'. The study of Oldewage-Theron, Dicks and Napier (2006:799) showed that poverty, food insecurity, malnutrition and poor health are major problems in this area.

\section{Population and sampling}

The study respondents were schoolchildren aged between 7 and 11 years, who were attending the only primary school in the informal settlement. It was decided to choose those between 7 and 11 years because they would be able to understand and complete the questionnaires. The first contact was made through a visit to the Department of Education to obtain permission to conduct the study in a government primary school; thereafter, the school management gave its consent to continue with the study. A power calculation was done to determine the sample size required for the study. A sample size of 133 was needed for a power of $95 \%$ (The Survey System). Written consent was sought from all the parents of the Grade 1-5 children (aged $7-11, n=358$ ) in order to sample respondents from the children with informed consent. A total of 149 parents and children gave consent to participate in the study and all were included. The remaining 209 parents did not respond timeously to the invitation to participate and were not included in the study. Anonymity of the data was ensured by allocating a number to each respondent. Ethical clearance was obtained from the Medical Ethical Research Committee of the University of Witwatersrand (Protocol no. M03-05-06).

\section{Measuring instruments and procedures}

Three sets of questionnaires were used to collect data for this study. These comprised a socio-demographic questionnaire (Oldewage-Theron et al. 2005:19), a 24-hour recall questionnaire (Oldewage-Theron et al. 2005:19) and a validated, culturesensitive, quantified food frequency questionnaire (QFFQ) of foods consumed the previous month (MacIntyre, Venter \& Vorster 2001a:53; MacIntyre, Venter \& Vorster 2001b:63; MacIntyre, Venter \& Vorster 2001c:48). These questionnaires were previously developed and validated for use by Africans in the Gauteng and North-West provinces of South Africa and were completed with the assistance of trained fieldworkers in interviews with all the principal caretakers who gave consent for their children to participate in the study (mothers or grandmothers). Food models were used to determine portion sizes and to explain food items to the respondents. The 24-hour recall questionnaire was completed on two non-consecutive days that included a weekday and weekend day. Furthermore, two non-consecutive days were used because the children could not remember what they had eaten two days before. The 24hour recall questionnaires were thus completed on two separate days to record the intakes of the previous day. Dietary intakes were analysed with the FoodFinder ${ }^{\circledR}$ version 3 program that is based on South African food composition tables (Langenhoven et al. 1991). Furthermore, the mean phytate : zinc ratio of the children's diet was calculated to assess the bioavailability of zinc in the diet. The ratio was calculated for each individual using the following equation: (mg phytate per day/660) $\div$ (mg zinc per day/65.4) (Gibson \& Ferguson 2000). However, phytate values are missing for a large number of food items in South African food composition tables, including maize meal, the major food item in the children's diet. Therefore, the results of Pisa (2006:30), who recently analysed samples of maize meal from six provinces in South Africa for their phytate content, were included in the dietary analysis. Pisa requested samples of $2 \mathrm{~kg}$ maize meal from the major millers (supplying more than $75 \%$ of the maize meal consumed) in each of the nine provinces. Millers from six provinces complied with the request. The other three provinces did not comply on the basis that they did not have their own maize millers and depended on other provinces for their maize meal supply. The Wheeler and Ferrel method (Wheeler \& Ferrel 1971:315), with slight modifications, was used for the determination of the phytate content at the North-West University, Potchefstroom campus (Pisa 2006:31). The analysis was done in triplicate and the results were verified by an agricultural research laboratory.

A limitation of the study was that not all the measurements could be taken on one day, due to school attendance and the caregivers' inability to stay for a long period of time. The questionnaires were thus completed on one day and the anthropometric and biochemical measurements on the same day a week later. This resulted in not all the children being present the next week and anthropometric measurements and biochemical indices of a subset of 113 children were thus determined. Mass was measured on a Philips electronic bathroom scale (model HF350) and height was measured with a Scales 2000 portable stadiometer. Body mass, with the children in light clothing and barefoot, was determined to the nearest $0.1 \mathrm{~kg}$ and height to the nearest $0.5 \mathrm{~cm}$ on the stadiometer. All measurements were taken twice and the average of the two measurements was recorded as a standardised practice to improve quality of anthropometric data.

On the day preceding blood sampling, children were instructed to refrain from eating breakfast the next morning. As soon as they arrived at school, a fasting venous blood sample $(10 \mathrm{~mL}$ from each child) was taken by six registered nursing sisters, wearing disposable polyethylene gloves, free of talc or any other coatings, using a stainless steel Vacutainer needle with minimal use of tourniquets. It has been reported that prolonged use of tourniquets may result in an increase in serum or plasma zinc levels; hence they should be used for about one minute only (Gibson 2005:717). Blood was drawn into trace-element- 
TABLE 1

Anthropometric indices of primary school children

\begin{tabular}{|c|c|c|c|c|c|c|}
\hline \multirow{2}{*}{$\begin{array}{l}\text { Anthropometric index } \\
\text { (Prevalence) }\end{array}$} & \multicolumn{2}{|c|}{ Boys $(n=50)$} & \multicolumn{2}{|c|}{ Girls $(n=63)$} & \multicolumn{2}{|c|}{ Total $(n=113)$} \\
\hline & $n$ & $\%$ & $n$ & $\%$ & $n$ & $\%$ \\
\hline Stunting & 9 & 18 & 8 & 12.7 & 17 & 15 \\
\hline Severe stunting & 0 & 0 & 2 & 3.2 & 2 & 1.8 \\
\hline Thinness & 8 & 16 & 0 & 0 & 8 & 7.1 \\
\hline Severe thinness & 2 & 4 & 0 & 0 & 2 & 1.8 \\
\hline Overweight & 5 & 10 & 7 & 11.1 & 12 & 10.6 \\
\hline Obesity & 1 & 2 & 3 & 4.8 & 4 & 3.5 \\
\hline \multicolumn{7}{|l|}{ Z-scores (mean \pm s.d.) } \\
\hline Height-for-Age Z scores & \multicolumn{2}{|c|}{$-0.46 \pm 1.29$} & \multicolumn{2}{|c|}{$-0.65 \pm 1.19$} & \multicolumn{2}{|c|}{$-0.56 \pm 1.23$} \\
\hline BMI-for-Age Z scores & \multicolumn{2}{|c|}{$-0.56 \pm 1.43$} & \multicolumn{2}{|c|}{$-0.33 \pm 1.05$} & \multicolumn{2}{|c|}{$-0.43 \pm 1.23$} \\
\hline
\end{tabular}

free, evacuated tubes without anti-coagulant, using siliconised stoppers. The blood was taken and anthropometry carried out for all 113 children on the same day and, because there were six registered nursing sisters, the procedure lasted for only two hours, between 07:00 and 09:00. The children were served breakfast immediately after blood collection. The blood was placed on ice until separation within two hours and separated plasma and serum were aliquoted in marked Eppendorf test tubes. All blood parameters were analysed according to standard protocol and all equipment used (excluding the disposable items) were decontaminated before use. Serum zinc was determined by the atomic absorption spectroscopy (AAS) method as described by Smith, Butrimovitz and Purdy (1979:1487), as well as Burtis and Ashwood (1999:326). This method uses a fivefold diluted serum and calibrator in 5\% glycerol matrixes, which are aspirated into the atomic absorption flame. The zinc concentration is determined by comparing the signal from diluted serum with the signal from aqueous calibrators, which is prepared in a diluted glycerol matrix $(5 \mathrm{~mL} / \mathrm{dL})$ to simulate the viscosity of diluted serum. The coefficient of variation (s.d./mean x 100\%) for serum zinc was $15 \mu \mathrm{g} / \mathrm{dL}$.

\section{Statistical analysis}

Frequencies, percentages, means, standard deviations, analysis of variance and Pearson correlations were computed using the Statistical Package for Social Sciences (SPSS) version 14.0.

TABLE 2

Top 20 food items consumed in largest amounts per child (aged 7-11 years) per day as measured by QFFQ for all children $(n=149)$

\begin{tabular}{llll}
\hline Rank & Food item & $\begin{array}{l}\text { Mean daily } \\
\text { intake (grams } \\
\text { per person) }\end{array}$ & $\begin{array}{l}\text { Number of children } \\
\text { consuming the food } \\
\text { item (\%) }\end{array}$ \\
\hline 1 & Maize meal porridge, stiff & 404 & $99(66)$ \\
2 & Tea, brewed & 203 & $93(62)$ \\
3 & Maize meal porridge, soft & 137 & $53(36)$ \\
4 & Bread, brown & 56 & $88(59)$ \\
5 & Sorghum porridge & 79 & $60(40)$ \\
6 & Rice & 39 & $100(67)$ \\
7 & Cold drink, squash & 53 & $67(45)$ \\
8 & Maize meal porridge, crumbly & 87 & $39(26)$ \\
9 & Cold drink, carbonated & 66 & $50(34)$ \\
10 & Milk, full-cream & 47 & $70(47)$ \\
11 & Coffee, brewed & 81 & $39(26)$ \\
12 & Apple, raw & 28 & $99(66)$ \\
13 & Pear, raw & 47 & $56(38)$ \\
14 & Banana, peeled & 32 & $76(51)$ \\
15 & Tomato and onion sauce & 18 & $97(65)$ \\
16 & Orange, fresh & 31 & $43(29)$ \\
17 & Rooibos tea, brewed & 221 & $4(3)$ \\
18 & Sugar, white, granulated & 9 & $98(66)$ \\
19 & Samp and beans & 42 & $12(8)$ \\
20 & Bread, white & 29 & $7(5)$ \\
\hline & & & \\
\hline
\end{tabular}

Anthropometric data were analysed using the World Health Organization (WHO) Anthro plus version 1.0.2 statistical software. Stunting was defined as height-for-age $z$-score $<-2 S D$ (Severe stunting, <-3SD), thinness as BMI-for-age z-score <-2SD (Severe thinness, <-3SD) and overweight as $>+1$ SD (Obesity, $>+2 \mathrm{SD})$.

\section{RESULTS}

The mean age of the children was $9.0 \pm 1.1$ years. All the respondents resided in the selected poor, peri-urban informal settlement in the Vaal region. The results of this study indicated that $90 \%$ ( $n$ $=134)$ of the children lived in a makeshift zinc shack, with $31 \%(n$ $=46)$ having fewer than two rooms per house, $44 \%(n=66)$ having three to four rooms and only $25 \%(n=37)$ having more than four rooms. All respondents had access to safe, clean, running water, albeit outside the houses. The bucket-system toilet facility was used by $98 \%(n=146)$ of the respondents.

Data in Table 1 show the anthropometric status of the children. Prevalence of stunting was high $(15.3 \%)$, with a higher percentage among boys than girls, while $16 \%$ of the boys were thin, none of the girls fell into this category. However, mean height-for-age and mean BMI-for-age z-scores did not differ significantly between boys and girls.

Concerning total food and nutrient intake, the results revealed that the diet was predominantly plant-based, consisting primarily of stiff maize meal porridge and tea, with a mean daily intake of $404 \mathrm{~g}$ and $203 \mathrm{~g}$ respectively (Table 2). No zincrich sources appeared in the list of the top 20 foods consumed (ranked by multiplying mean quantity consumed by the number of children consuming the food item).

TABLE 3

Mean dietary intake of energy, protein, zinc and phytate of the children from 24-hour recall $(n=149)$

\begin{tabular}{|c|c|c|}
\hline \multirow[t]{2}{*}{ Mean nutrient intake per day } & Mean \pm s.d. & \multirow[t]{2}{*}{ EAR } \\
\hline & (\% EAR) & \\
\hline \multirow[t]{2}{*}{ Energy $(\mathrm{kJ})$} & $5121 \pm 2399$ & \multirow[t]{2}{*}{$7129^{\mathrm{a}} / 7740^{\mathrm{b}}$ * } \\
\hline & $\left(72^{\mathrm{a}}, 66^{\mathrm{b}}\right)$ & \\
\hline \multirow[t]{2}{*}{ Total protein $(\mathrm{g})$} & $37.8 \pm 19$ & \multirow[t]{4}{*}{$34^{\dagger}$} \\
\hline & 111 & \\
\hline Total plant protein (g) & $22.4 \pm 11$ & \\
\hline Total animal protein $(\mathrm{g})$ & $15.4 \pm 13$ & \\
\hline Zinc (mg) & $4.6 \pm 2.2$ & \multirow[t]{4}{*}{$4^{\mathrm{c}} 7^{\mathrm{d}}$} \\
\hline $7-8$ years & $4.8 \pm 2.0$ & \\
\hline $9-11$ years & $4.5 \pm 2.3$ & \\
\hline Phytate (mg) & $49 \pm 91$ & \\
\hline
\end{tabular}


Table 3 shows the mean energy, protein, zinc and phytate intakes of the children. The mean dietary zinc intake was $4.6 \pm 2.2 \mathrm{mg} /$ day. The Estimated Average Requirement (EAR) of zinc given according to life-stage and diet-type for populations consuming a predominantly plant-based diet of low zinc bioavailabilty, is 4 $\mathrm{mg}$ /day for children aged 4-8 years and $7 \mathrm{mg} /$ day for children aged 9-13 years (Institute of Medicine 2003:53). In this study, the children were aged 7-11 years; this crosses the two age groups just mentioned (4-8 years and 9-13 years), hence the analysis was done to reflect this. The younger age group in the sample (7-8 years) had higher mean zinc intakes compared to the older group (9-11 years), though the difference was not statistically significant. However, there was a significant difference in the percentage below the respective EARs; this was $16.2 \%$ for the younger-aged group and $83.5 \%$ for the older group $(p<0.05)$.

As a measure of zinc bioavailabilty in the children's diet, the phytate : zinc molar ratio of the diet was also computed. The mean phytate content of the diet was calculated to be $49 \pm 91$ $\mathrm{mg}$ for the average of the two 24-hour recall measurements. However, these values are likely to be an underestimation of the phytate content of the diet. This is because in South African food composition tables (Langenhoven et al. 1991), which were used in analysing the data, phytate values are missing for maize meal, the major food item in the children's diet. The phytate content of maize meal, as determined by Pisa (2006:32), ranged from 1237 $\mathrm{mg} / 100 \mathrm{~g}$ to $1631 \mathrm{mg} / 100 \mathrm{~g}$ maize meal, with an average of 1468 $\mathrm{mg} / 100 \mathrm{~g}$ maize meal supplied in Gauteng province. The mean of the individual phytate : zinc ratios obtained was 36.9, perhaps indicating a diet of low zinc bioavailability.

The present data showed that the mean total maize meal intake per child was $114 \mathrm{~g}$ per day (raw mass). This was the equivalent of all the cooked maize meal porridge portions as indicated in the top 20 most frequently consumed food items in this study. This $114 \mathrm{~g}$ raw maize meal should have contributed $1673.5 \mathrm{mg}$ phytate, based on the laboratory figure for Gauteng (Pisa 2006:32), where the present study was also conducted. Therefore, the total of $1673.5 \mathrm{mg}$ of phytate supplied by the maize meal was added to the total phytate content as measured by 24-hour recall, giving a total estimated value of $1722.5 \mathrm{mg}$

The mean value of serum zinc was $66.4 \pm 21.5 \mu \mathrm{g} / \mathrm{dL}$ (Table 4 ). The current suggested lower cut-off values of the IZiNCG for the assessment of serum zinc concentration are $74 \mu \mathrm{g} / \mathrm{dL}$ for boys and $70 \mu \mathrm{g} / \mathrm{dL}$ for girls ( $\geq 10$ years) for morning fasting blood samples (Hotz \& Brown 2004:S145). However, there is no cut-off available for children younger than 10 years in the category of samples collected in the morning from fasting subjects. Thus, in this study, the cut-off of $70 \mu \mathrm{g} / \mathrm{dL}$ was used, as the age groups of the respondents in this study were both under and over 10 years of age (mean age $9.0 \pm 1.1$ years). The results indicated that $46 \%$ of the children had values less than the $70 \mu \mathrm{g} / \mathrm{dL}$ cut-off value. Of those with suboptimal serum zinc levels, $11.5 \%$ and $34.5 \%$ fell into the younger and older age group, respectively. The mean serum zinc values were lower for boys than for girls, lower in the older age group than the younger and also lower in the

TABLE 4

Serum zinc levels of primary school children $(n=133)$

\begin{tabular}{ll}
\hline Characteristic & Serum zinc (mean \pm s.d.) \\
\hline Sex & $62.8 \pm 23.0$ \\
Boys & $69.2 \pm 20.0$ \\
Girls & \\
Age group & $69.8 \pm 21.5$ \\
$7-8$ years & $64.6 \pm 21.4$ \\
9-11 years & \\
Anthropometric status & $64.6 \pm 21.8$ \\
Stunted & $66.8 \pm 21.5$ \\
\hline
\end{tabular}

All figures are measured in $\mu \mathrm{g} / \mathrm{dL}$. stunted group than the non-stunted group, even though there is no statistical significance (Table 4). Serum zinc concentration was positively but weakly correlated with dietary zinc intake ( $\mathrm{r}$ $=0.276, p<0.01$ ).

\section{DISCUSSION}

As a result of the far-reaching effects of zinc deficiency in children with regard to stunting (Brown et al. 2001:114), as well as morbidity from diarrhoea, pneumonia and malaria (Shankar 2000:S38) and the effect on cognitive development (Black 1998:464S), this study assessed the dietary intake and biochemical zinc status of a group of schoolchildren living in a low-socio-economic, peri-urban informal settlement in South Africa, in order to plan intervention studies should zinc deficiency be a problem.

The findings of this study confirm a high risk of zinc deficiency and suboptimal zinc statuses for the majority of the population sample studied. The estimated proportion of children with dietary zinc intakes below the EAR was high, particularly among the older children, indicating an elevated risk of zinc deficiency among these children on the verge of onset of puberty. The results of the NFCS also indicated inadequate zinc intake among children from 1-9 years old (Labadarios et al. 2005:488). Similarly, the $46 \%$ prevalence of suboptimal serum zinc concentrations is very high when compared with the $20 \%$ prevalence set by the IZiNCG (2007), an indicator of the zinc deficiency risk of significant public health importance, and higher than the prevalence of $31.1 \%$ found among adolescents (mean age 13.2 \pm 1.0 years) of Tehran City (Mahmoodi \& Kimiagar 2001:93), but lower than the $57 \%$ found by Thurlow et al. (2006:623) among schoolchildren in eastern Thailand. Hence, the findings of this study agree with these previous studies that demonstrated the existence of zinc deficiencies among children of school age and early adolescence. An aspect of this study that differs from the recently published work on primary school children in Thailand, in which zinc deficiency has been associated with impairments in linear growth among schoolchildren in north-eastern Thailand (Gibson et al. 2007:167), is that there was no significant association between serum zinc and stunting. There was no significant gender difference in the prevalence of low serum zinc concentrations. This, however, differs from other studies, which have reported a greater vulnerability of boys to zinc deficiency than girls, probably owing to a higher need for the nutrient (Cavan et al. 1993:345). Nevertheless, there is a predominance of literature suggestive of the fundamental importance of zinc in the growth and development of children.

The association between serum zinc and zinc intake, when considered in addition to the dietary pattern as revealed by the top foods commonly consumed, shows an agreement between inadequate intakes and biochemical measures. Based on the dietary assessment, the diet is mainly plant-based, with low zinc bioavailability as deduced from the adjusted mean phytate : zinc ratio of 36.9, based on the results of Pisa (2006). The phytate content and phytate : zinc molar ratio reported in the literature show large variation. Guansheng et al. (2005:10287) and Lestienne et al. (2005:424) who analysed maize meal in China and France respectively, reported phytate : zinc molar ratios of 48.2 and 40.6, while Hotz and Gibson (2001:692) reported phytate : zinc molar ratios of 28.9 for maize flour and 28.8 for pounded maize in Malawi. However, plant-based diets with phytate : zinc ratios above 18 are classified as having low zinc bioavailability (IZiNCG 2007:1), and can therefore impinge on zinc status. Phytic acid reduction in cereal grains has been accomplished with plant genetic techniques. These low-phytic acid grains provide a strategy for improving the mineral (e.g. zinc) status in populations that are dependent on grains, including maize (Zea mays L.), as major dietary staples (Adams et al. 2002:557).

Based on the results of this study, the aetiology of zinc deficiency in this sample of primary school children is suggested to be an outcome of a combination of high phytate content in the diet due to the high proportion of energy from cereals, mainly 
refined maize meal, and low consumption of animal sources of zinc, which is invariably a direct consequence of poverty and food insecurity in this informal settlement. At the time of data collection, the fortification of maize meal had not been legislated in South Africa. After this study was completed, all maize meal in South Africa has been fortified with zinc oxide of $93.4 \mathrm{~g} / \mathrm{kg}$, as recommended by the authors of the NFCS (Labadarios et al. 2005:542), contributing $18.5 \mathrm{mg}$ of zinc per kilogram of maize meal (Department of Health 2002). A portion size of $404 \mathrm{~g}$ of stiff and $137 \mathrm{~g}$ soft maize meal porridge (equivalent of $114 \mathrm{~g}$ raw maize meal for the portions of stiff, soft and crumbly maize meal combined), as consumed by this sample, would thus contribute an extra $2.1 \mathrm{mg}$ zinc (30\% of EAR) to the daily diet. In a followup of the NFCS, the impact of food fortification on the nutritional status of South African children has been determined, and has indicated that suboptimal zinc status remains a public health problem. Nationally, $45.3 \%$ of children aged 1-9 years still had an inadequate zinc status (Labadarios et al. 2008:284). Food fortification may be one of the solutions to address micronutrient malnutrition; however, other solutions should also be designed and implemented in the context of this reality of the basic causes of malnutrition.

\section{LIMITATIONS OF THE STUDY}

A limitation of this study was that different measurements were taken on different days and a full set of data was thus not obtained for all the respondents, hence the dietary intake measurements of 149 children compared to the biochemical and anthropometric measurements of only 113 respondents. Furthermore, because of the lack of phytate content of South African maize meal in the national food composition tables, the calculation of the phytate intake and phytate : zinc ratio was based on the results of Pisa (2006:32) of maize meal supplied by the major millers in Gauteng, which needs to be confirmed by further research and included in the South African food composition tables.

\section{CONCLUSION AND RECOMMENDATIONS}

The results of this study will form the basis for planning sustainable community-based intervention strategies to improve the zinc status of schoolchildren in this informal settlement. These include dietary intervention strategies involving dietary diversification, particularly with respect to enhancing intake of total bioavailable zinc, specifically by increasing intakes of cheaper protein sources such as skimmed milk powder (relatively cheap and also a good source of calcium to improve both zinc and calcium intake), chicken, eggs and pilchards (a relatively cheap dish, very popular among South African Black people). Projects such as raising chickens and goats and implementation of school feeding programmes can be promoted. Poverty alleviation and sustainable livelihood projects are also anticipated as further means to address the problem at its roots.

These interventions are imperative in view of the well-known adverse consequences of zinc deficiency to the health and quality of life of school-aged children, particularly in terms of academic performance. Although the mechanisms involved are not currently fully understood, it appears that zinc deficiency may undermine cognitive development through alteration in attention, activity and other aspects of neuropsychological function, as it contributes to the structure and function of the brain (Black 2003:3927S; Sandstead 2000:S347). Zinc also plays a role in ensuring optimal growth, immune function, work capacity, sexual maturation and bone mineralisation in preadolescents and adolescents. Further research is needed to evaluate the impact and effectiveness of community-based intervention strategies to alleviate zinc deficiency among school children in low-income neighbourhoods.

\section{ACKNOWLEDGEMENTS}

We hereby acknowledge the Vaal University of Technology and National Research Foundation for funding this project, as well as the management and children of the primary school for their co-operation. Furthermore, we acknowledge the fieldworkers who assisted with the collection of data, Verena Nolan (statistician) and Lizelle Oosthuizen (dietician and research assistant) for their valuable assistance.

\section{REFERENCES}

Adams, C.L., Hambidge, M., Raboy, V., Dorsch, J.A., Sian, L., Jamie L. et al., 2002, 'Zinc absorption from a low-phytic acid maize', American Journal of Clinical Nutrition 76(3), 556-559.

Black, M.M., 1998, 'Zinc deficiency and child development', American Journal of Clinical Nutrition 68, 464S-469S.

Black, M.M., 2003, 'Micronutrient deficiencies and cognitive functioning', Journal of Nutrition 133, 3927S-3931S.

Brown, K.H., Wuehler, S.E. \& Peerson, J.M., 2001, 'The importance of zinc in human nutrition and estimation of the global prevalence of zinc deficiency', Food and Nutrition Bulletin 22(2), 113-125.

Burtis, C.A. \& Ashwood, E.R. (eds.), 1999, Tietz textbook of clinical chemistry, 3rd edn., W.B. Saunders \& Company, Philadelphia.

Caulfield, L. \& Black, R.E. 2004, 'Zinc deficiency', in M. Ezzati, A.D. Lopez, A. Rodgers \& C.J.L. Murray (eds.), Comparative quantification of health risks: Global and regional burden of disease attributable to selected major risk factors vol. 1, pp. 257279, World Health Organization, Geneva.

Cavan, K.R., Gibson, R.S., Grazioso, C.F., Isalgue, A.M., Ruz, M. \& Solomons, N.W., 1993, 'Growth and body composition of periurban Guatemalan children in relation to zinc status: a cross-sectional study', American Journal of Clinical Nutrition $57,344-352$.

Charlton, K.E., Bourne, L.T., Steyn, K. \& Laubscher, J.A., 2001, 'Poor nutritional status in older black South Africans', Asian Pacific Journal of Clinical Nutrition 10(1), 31-38.

Dannhauser, A., Bester, C.J., Joubert, G., Badenhorst, P.N., Slabber, M., Badenhorst, A.M. et al., 2000, 'Nutritional status of preschool children in informal settlement areas near Bloemfontein, South Africa', Public Health Nutrition 3(3), 303-312.

Department of Health, 2002, Foodstuffs, Cosmetics and Disinfectants Act, 1972 (Act No. 54 of 1972), 'Regulations relating to the fortification of foodstuffs', viewed 8 November 2006, from http://www.doh.gov.za/docs/regulations/foodstuff/ fortification.html

Engelbrecht, K. \& Du Rand, P., 2001, 'Status of frail elderly black people in informal settlements', South African Continued Medical Education Monthly 18(10), 828-833.

Faber, M., Jogessar, V.B. \& Benadé, A.J.S., 2001, ‘Nutritional status and dietary intakes of children aged $2-5$ years and their caregivers in a rural South African community', International Journal of Food Science and Nutrition 52(5), 401411.

Gibson, R.S., 1994, 'Zinc nutrition in developing countries', Nutrition Research Reviews 7, 151-173.

Gibson, R.S., 2005, Principles of nutritional assessment, 2nd edn., Oxford University Press, New York.

Gibson, R.S., 2006 'Zinc: The missing link in combating micronutrient malnutrition in developing countries', Proceedings of the Nutrition Society 65(1), 51-60.

Gibson, R.S. \& Ferguson, E.L., 2000, 'An interactive 24-hour recall for assessing the adequacy of iron and zinc intakes in developing countries', viewed 12 August 2007, from http:// www.ilsi.org/hni.html

Gibson, R.S., Manger, M.S., Krittaphol, W., Pongcharoen, T., Gowachirapant, S., Bailey, K.B. et al., 2007, 'Does zinc deficiency play a role in stunting among primary school children in NE Thailand?', British Journal of Nutrition 97(1), 167-175.

Guansheng, M., Ying, J., Jianhua, P. \& Frans, K., 2005, 'Phytate, calcium, iron and zinc contents and their molar ratios in foods commonly consumed in China', Journal of Agricultural and Food Chemistry 53, 10285-10290.

Hotz, C. \& Brown, K.H., 2004, 'Assessment of the risk of zinc deficiency in populations and options for its control', Food and Nutrition Bulletin 25(1), S94-S200. 
Hotz, C. \& Gibson, R., 2001, 'Assessment of home-based processing methods to reduce the phytate content and phytate/zinc molar ratio of white maize (Zea mays)', Journal of Agricultural and Food Chemistry 49, 692-698.

Hugo-Hamman, C.T., Kibel, M.A., Michie, C.A. \& Yach, D., 1987, 'Nutrition status of pre-school children in a Cape Town township', South African Medical Journal 72, 353-355.

International Zinc Nutrition Consultative Group (IZiNCG), 2007, 'Determining the risk of zinc deficiency: Assessment of dietary zinc intake', IZiNCG Technical Brief 3, 1-4.

Institute of Medicine, 2003, Dietary reference intakes, food and nutrition board, National Academy Press, Washington D.C.

Labadarios, D., Steyn, N.P., Maunder, E., MacIntyre, U., Gericke, G., Swart, R. et al., 2005, 'The National Food Consumption Survey (NFCS), South Africa, 1999', Public Health Nutrition 8(5), 533-543.

Labadarios, D., Swart, R., Maunder, E.M.W., Kruger, H.S., Gericke, G.J., Kuzawayo, P.M.M. et al., 2008, 'Executive summary of the National Food Consumption Survey Fortification Baseline (NFCS-FB-I), South Africa, 2005,' South African Journal of Clinical Nutrition 21(3, suppl. 2), 245300.

Langenhoven, M., Kruger, M., Gouws, E. \& Faber, M., 1991, South African food composition tables, 3rd edn., Medical Research Council, Cape Town.

Lestienne, I., Icard-Verniere, C., Mouquet, C., Picq, C. \& Treche S., 2005, 'Effects of soaking whole cereal and legume seeds on iron, zinc and phytate contents', Food Chemistry 89, 421425.

MacIntyre, U.E., Venter, C.S. \& Vorster, H.H., 2001a, 'A culturesensitive quantitative food frequency questionnaire used in an African population: 1. Development and reproducibility', Public Health Nutrition 4(1), 53-62.

MacIntyre, U.E., Venter, C.S. \& Vorster, H.H., 2001b, 'A culturesensitive quantitative food frequency questionnaire used in an African population: 2. Relative validation by 7-day weighed records and biomarkers', Public Health Nutrition 4(1), 63-71.

MacIntyre, U.E., Venter, C.S., Vorster, H.H. \& Steyn, H.S., 2001c, 'A combination of statistical methods for the analysis of the relative validation data of the quantitative food frequency questionnaire used in the THUSA study', Public Health Nutrition 4(1), 45-51.

Mahmoodi, M.R. \& Kimiagar, S.M., 2001, 'Prevalence of zinc deficiency in junior high school students of Tehran City', Biological Trace Element Research 81(2), 93-103.

Manary, M,J., Hotz, C., Krebs, N.F., Gibson, R.S., Westcott, J.E. \& Broadhead, R.L., 2002, 'Zinc homeostasis in Malawian children consuming a high-phytate, maize-based diet', American Journal of Clinical Nutrition 75, 1057-1061.
Mazariegos, M., Hambidge, K.M., Krebs, N.F., Westcott, J.E., Lei, S., Grunwald, G.K. et al., 2006, 'Zinc absorption in Guatemalan schoolchildren fed normal or low-phytate maize', American Journal of Clinical Nutrition 83, 59-64.

McIlrath, L. \& Slabbert, T., 2003, 'Sedibeng Economic Regeneration Summit', Sedibeng Municipality, Vanderbijlpark.

Oelofse, A., Van Raaij, J.M.A., Benadé, A.J.S., Dhansay, M.A., Tolboom, J.J.M. \& Hautvast, J.G.A.J., 2002, 'Disadvantaged black and coloured infants in two urban communities in the Western Cape, South Africa differ in micronutrient status', Public Health Nutrition 5(2), 290-294.

Oldewage-Theron, W.H., Dicks, E.G., Napier, C.E. \& Rutengwe, R., 2004, 'A community-based integrated nutrition research programme to alleviate poverty: Baseline survey', Public Health 119, 312-320.

Oldewage-Theron, W.H., Dicks, E.G., Napier, C.E. \& Rutengwe, R., 2005, 'Situation analysis of an informal settlement in the Vaal Triangle', Development Sothern Africa 22(1), 13-26.

Oldewage-Theron, W.H., Dicks, E.G., \& Napier, C.E., 2006 , 'Poverty, household food insecurity and nutrition: Coping strategies in an informal settlement in the Vaal Triangle, South Africa', Public Health 120, 795-804.

Pisa, P., 2006, Determination of phytate, iron, calcium, zinc and the phytate to mineral molar ratios in maize meal from six South African provinces, BSc (Hons) dissertation, North-West University, Potchefstroom.

Prasad, A.S., 2007, 'Zinc: Mechanisms of host defense', Journal of Nutrition 137, 1345-1349.

Sandstead, H.H., 2000, 'Causes of iron and zinc deficiencies and their effects on the brain', Journal of Nutrition 130, 347S-349S.

Shankar, A.H., 2000, 'Nutritional modulation of malaria morbidity and mortality', Journal of Infectious Diseases 182(suppl.), S37-53.

Smith, J.C., Butrimovitz, G.P. \& Purdy, W.C., 1979, 'Direct measurement of zinc by atomic absorption spectroscopy', Clinical Chemistry 25, 1487-1491.

The Survey System, 'Sample size calculator', viewed 22 July 2008, from http://www.surveysystem.com/ssformu.htm

Thurlow, B.A.,Winichagoon,P.,Pongcharoen, T., Gowachirapant, S., Boonpraderm, A., Manger, M.S. et al., 2006, 'Risk of zinc, iodine and other micronutrient deficiencies among school children in North-East Thailand', European Journal of Clinical Nutrition 60, 623-632.

Wheeler, E.L. \& Ferrel, R.E., 1971, 'A method for phytic acid determination in wheat and wheat fractions', Cereal Chemistry 48, 312-320.

World Health Organization (WHO), 'Anthro plus version 1.0.2.', viewed 22 March 2009, from http://www.who.int/ growthref 